Author: Jan Obrębski

Title of article: „Analiza stanów krytycznych mostu w czasoprzestrzeni” („Analysis of critical state for bridge in 3D-time space”)

Mechanik, Vol. 91, No. 7 (2018): pages 591-593

DOI: https://doi.org/10.17814/mechanik.2018.7.93

\title{
Analysis of critical state for bridge in 3D-time space
}

\author{
Analiza stanów krytycznych mostu w czasoprzestrzeni
}

\begin{abstract}
JAN OBRĘBSKI *
\end{abstract}
In the paper was pointed possibility to evaluate critical state of bridge under travelling loading, applying uniform criterion for geometrical changeability and instability of structure and 3D-time space method modelled by Finite Differences (FD). The both numerical methods are formulated by present author. In the above criterion is used value of main determinant of dynamical stiffness matrix for bridge or even for task, when loading is travelling beyond span. Results show efficacy of the method and influence of some parameters.

KEYWORDS: dynamics, 3D-time space, finite differences, bridge, critical state

Work is a major step in the study of space-time applications (hereinafter: CzP (from Polish letters) and a uniform criterion - formulated by the author - for the analysis of critical states of the structure. A broader view of the development of the application of the $\mathrm{CzP}$ for the dynamic analysis of various structures was presented during the previous International School of Computer Aided Design, Manufacturing and Operation [17] and in the author's publications in the LSCE conference books.

In the mentioned method, as the fourth - time is added to the three dimensions for description of the task. A major contribution to the application of the $\mathrm{CzP}$ for mechanical tasks was made by: Z. Kączkowski [4-6], who introduced the formalism of the finite element method, as well as his collaborators [17], who used the CzP in a different approach. According to this concept, they made examples of rather simple technical tasks. Of course, their research was preceded by a series of works by other authors.

A breakthrough in this area was a doctorate, R. Szmit's [20]. There, to analyze the behavior of the high building, the author used a numerical approach using CzP along with the Finite Difference Method (FDM). It turned out to be fully effective. The only difficulty was the proper selection of the so-called time step. Ultimately, this approach was named 3D-TSM (3D-time space method).

Almost parallel to the works of R. Szmit, the author of this article and the originator of the method made numerous examples concerning other engineering structures - mobile loads on bridges, roads and airport runways. He tested bar and plate models.

Some tasks were calculated - as housework (2017) - by students of structural theory (A. Franus, J. Kutyna, J. Rawiak, Ł. Rogula and T. Tarabasz), using commercial

\footnotetext{
* Prof. dr hab. inż. Jan B. Obrębski (jobrebski@poczta.onet.pl) - retired
} full Professor of Warsaw University of Technology programs available at the Faculty of Civil Engineering of the Warsaw University of Technology. This gave an assessment of the effectiveness of the method and quality of results for the bridge with a cross-section from fig. 1.

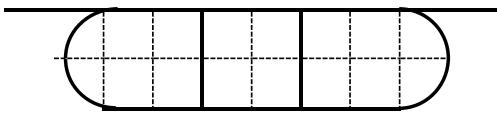

Fig. 1. Analyzed cross-section of a steel bridge, close to the real one $[17,18]$

The calculations made by students were burdened with errors, therefore the author undertook extensive work aimed at obtaining correct results, which will be published separately. After adjusting the scope of work entrusted to students, calculations were carried out for masses of $20 \mathrm{t}$ and $100 \mathrm{t}$, moving at different speeds on the span: $L=50$, $60,70,80,90$ and $100 \mathrm{~m}$. Also the influence of the girder division density on the sections $n=8$ or $n=10$ was estimated, too. A side effect of this research is this work, focused on the critical states of the dynamics of the bridge with the cross-section shown in fig. 1, with assumptions similar to those given to students. The basic tools used were the following: a uniform criterion for assessing geometrical variability and loss of structural stability (JK GZ + US (from Polish letters) [9-11, 14-16] and 3D-TSM $[12,13,17]$.

\section{Uniform criterion (JK GZ + US (from Polish letters)}

For the examination of the value of the Main Determinant (MD) of the stiffness matrix $\left(K,(6)_{1}\right)$ attention was drawn in the book [1], where was corroborated, that: "in the numerical calculations, the matrix value of the system coefficients of equilibrium equations of all nodes must be different from zero (...)". "Otherwise, this means geometrical variation(GV) of the bar system". This publication underlined the timeconsuming nature of the method. It is reported that the analysis of the 238 knots structure and 792 bars in the program written in ALGOL 60 took 90 minutes (in 1970).

Currently, it can be stated that this is a strict method, the most ingenious and effective, taking as a measure the zero value $M D$ of the matrix $K$ of the system, where $\Delta=\operatorname{det}[K]=$ 0 indicates GV or loss of stability. This condition was used by the author in WDKM and KMT programs [8, 2] for numerical verification, in two stages, GV of bar structures with any combination of rigid and articulated nodes. At the first stage, the computer checked, in the local sense, the postulates specified in the dissertation [8] and cited in book [2]. In the second stage, already after completion of the matrix $\mathrm{K}$, during determining the unknowns by the method of 
subsequent Gaussian elimination,MD values were calculated according to the formula [7]:

$$
\Delta=\operatorname{det}[\mathrm{K}]=\mathrm{K}_{11} \mathrm{~K}^{1}{ }_{22} \mathrm{~K}^{2}{ }_{33} \ldots \ldots . . \mathrm{K}^{1-1} \| \ldots \ldots . \mathrm{K}^{n-1} n n
$$

It is the product of words standing on the main diagonal modified after $n$ elimination of the stiffness matrix, in the row with the number $n$ (with some limitations - see [8]).

It should also be pointed out that in the case of analytical solutions formulated by Euler, the critical force was determined by equating to zero one expression obtained on the basis of differential equation and boundary conditions. A similar procedure was used to determine (critical) natural frequencies [3]. Vlasov also used the equation to zero of the determinant obtained on the basis of the system of three differential equations (see among others $[9,10]$ ).

Also in the handbook [9] an example is given to determine - with a uniform criterion - a critical condition for a bar loaded with longitudinal force $P$ and oscillating with the frequency of vibrations $\omega$. Further, in papers $[15,16]$, examples of various combinations of longitudinal and transverse loads resulting in the critical state of the bar were cited, and critical load limits and critical boundary surfaces were determined.

\section{Differential equations used}

In these tasks and in the doctorate of R. Szmit, the very general motion equations given in the manual [9] were used. It is a system of four differential equations of the second and fourth order, with derivatives relative to the coordinate $\eta$, calculated along the length of the beam, for the twisting angles and three displacements defined relative to the axis of the 3D reference system and time. In the general case, these equations are related to each other by displacements $\mathrm{V}_{i}$ (longitudinal, transverse) and torsion angle $\Theta$ counted around with regard o the longitudinal axis of the bar. They describe both free and forced vibrations as well as their interaction the surrounding center (interaction), including ground, air and water.

These general motion equations were initially developed for the theory of thin-walled bars. This theory includes statics, dynamics and second order theory, including the stability of a single bar. Prismatic bars may in this theory have any cross-sections, consisting of several materials, open and closed, and also have different boundary conditions defined. The surrounding medium can float the bar at a certain speed. Due to such assumptions, the theory is used in many tasks.

Works [15-17] show that the set of traffic equations for the bridge girder can be significantly simplified, omitting many words. This is due to the specificity of the task. In this way, there were used only two equations independent of each other, describing bending $v_{3}$ and twisting $\Theta$ (the marks are consistent with the works $[9,10,18]$ :

$$
\begin{gathered}
\bar{E} \bar{I}_{2} v_{3}^{I V}+\mu \ddot{v}_{3}-\ddot{v}_{3} I_{2 m}=q_{3}^{w}, \\
\bar{E} \bar{I}_{\hat{\omega}} \Theta^{I V}-K_{s} \Theta "+\ddot{\Theta}\left[I_{2 m}+I_{3 m}+\mu\left(\eta_{3 A}\right)^{2}\right]+ \\
-\ddot{\Theta} " I_{\hat{\omega} m}=m_{1}^{w} .
\end{gathered}
$$

\section{Differential equations of motion for bridge loads}

It was used to describe the task the $\mathrm{CzP}$ in numerical version 3D-TSM using MRS, too. This allows obtaining a bridge response to practically any mobile loads, and at the same time showing the deformations of the system in each of the considered time moments [17]. It was assumed that the bridge is a thin-walled beam with a length $L$, divided into $n$ sections of dimension $a=\Delta \eta=L / n$, with partition points with consecutive numbers $i$. The beam deflection line is defined in $m$ subsequent time moments denoted with numbers $t$.

Two differential equations of motion (2) and (3) were formally transformed to finite differences operators (4) and (5), replacing individual derivatives, including partial ones, with their finite differences equivalents [10]. The lower indices, separated by a comma, indicate the current point in space-time, marked with the index $(t, t)$. The same point and division of the beam in the previous moment were marked $(t-1, i)$, and for the next $(t+1, i)$. The vertical deflection of the beam was marked as $w=v_{3}$. After multiplication of equation (2) by $a_{4} / E_{12}$ and equations (3) by $a_{4} / E_{\text {lin }}$ and after rearrangement of words, independent differential equations of motion were obtained: for bending in the vertical plane (4) and for twisting (5):

$$
\begin{aligned}
w_{t-1, i-1} K_{1}+ & w_{t-1, i} K_{2}+w_{t-1, i+1} K_{1}+ \\
+w_{t, i-2}+ & w_{t, i-1} K_{3}+w_{t, i} K_{4}+w_{t, i+1} K_{3}+w_{t, i+2}+ \\
& +w_{t+1, i-1} K_{1}+w_{t+1, i} K_{2}+w_{t+1, i+1} K_{1}=Q \\
\Theta_{t-1, i-1} G_{1} & +\Theta_{t-1, i} G_{2}+\Theta_{t-1, i+1} G_{1}+ \\
+\Theta_{t, i-2} & +\Theta_{t, i-1} G_{3}+\Theta_{t, i} G_{4}+\Theta_{t, i+1} G_{3}+\Theta_{t, i+2}+ \\
& +\Theta_{t+1, i-1} G_{1}+\Theta_{t+1, i} G_{2}+\Theta_{t+1, i+1} G_{1}=S
\end{aligned}
$$

Symbols $K_{\mathrm{i}}$ and $G_{\mathrm{i}}$ are coefficients [18]. Three lines of these patterns describe the next moments of time.

\section{Differential dynamic bridge stiffness matrix}

After completion of the finite difference operators (4) and/or (5) for all division points of the beam, a dynamic stiffness matrix (DSM) is obtained containing information about the beam scheme, speed and the position of vehicles on the bridge for all assumed time moments (fig. 2). The task is to solve the system of linear algebraic equations (6) 1 [10]. If more than one differential motion equation-is used to describe the task, e.g. formulas (4) and (5), a differencematrix equilibrium equation of one node $(6)_{3}$ is obtained:

$$
\begin{gathered}
\mathrm{KX}=\mathrm{Q}, \\
C_{r} \sum_{t=1}^{t+1}\left(A_{r o}+\sum_{\Lambda=1}^{n} A_{r \Lambda} E_{\Lambda}\right) \Phi_{r}=Q_{r} \sum_{t-1}^{t+1}\left[\sum_{\Lambda=1}^{N}\left(W_{\Lambda}^{o}+W_{\Lambda} E_{\Lambda}\right)\right] x=q .
\end{gathered}
$$

It is then said about the Difference-Matrix Equations Method (DMEM) - in this case applied to space-time (see fig. 2). Such description was applied to a very numerically advanced computing system called WDKM [8]. The method of creating the DMS structure was given, among others in the works [12, 20,17]. Space-time as a computer method (3D-TSM) from the numerical point of view is a twodimensional task $[17,18]$. There, the construction equilibrium is considered together for all the time moments $t$.

Here $\mathrm{K}$ as DSM [12] has the number of rows and columns $N=I \times n \times m$, where $I$ is the number of motion equations describing the task (e.g. four or two - (4), (5)), $n$ number of beam division points, $m$ - the number of time points considered, separated from each other by a time segment $\Delta t$. Each element of global DSM - $K[N \times N]$ is a traditional stiffness matrix $K[w \times w]$, where $w=I \times n[17,18]$. As the boundary conditions traditional support of the structure [10] is taken into account as well as the initial condition for $t=0$ (known or equal to zero) and final condition (usually as the "back" difference). In work [18] two variants are also shown, when DSM form two equations describing bending (4) and twisting (5) 


\begin{tabular}{|c|c|c|c|c|c|c|c|c|}
\hline & $\mathrm{t}=1$ & $\mathrm{t}=2$ & $\mathrm{t}=3$ & $\mathrm{t}=4$ & $\mathrm{t}=5$ & $\mathrm{t}=6$ & $\mathrm{t}=7$ & \\
\hline $\mathrm{t}=1$ & $\mathrm{~K}_{\mathrm{r}}$ & $\mathrm{V}_{\mathrm{r}}$ & & & & & & $\mathrm{Q}_{1}$ \\
\hline $\mathrm{t}=2$ & $\mathrm{~V}_{\mathrm{r}}$ & $\mathrm{K}_{\mathrm{r}}$ & $\mathrm{V}_{\mathrm{r}}$ & & & & & $\mathrm{Q}_{2}$ \\
\hline $\mathrm{t}=3$ & & $\mathrm{~V}_{\mathrm{r}}$ & $\mathrm{K}_{\mathrm{r}}$ & $\mathrm{V}_{\mathrm{r}}$ & & & & $\mathrm{Q}_{3}$ \\
\hline $\mathrm{t}=4$ & & & $\mathrm{~V}_{\mathrm{r}}$ & $\mathrm{K}_{\mathrm{r}}$ & $\mathrm{V}_{\mathrm{r}}$ & & & $\mathrm{Q}_{4}$ \\
\hline $\mathrm{t}=5$ & & & & $\mathrm{~V}_{\mathrm{r}}$ & $\mathrm{K}_{\mathrm{r}}$ & $\mathrm{V}_{\mathrm{r}}$ & & $\mathrm{Q}_{5}$ \\
\hline $\mathrm{t}=6$ & & & & & $\mathrm{~V}_{\mathrm{r}}$ & $\mathrm{K}_{\mathrm{r}}$ & $\mathrm{V}_{\mathrm{r}}$ & $\mathrm{Q}_{6}$ \\
\hline $\mathrm{t}=7$ & & & & & & $\mathrm{~V}_{\mathrm{r}}$ & $\mathrm{K}_{\mathrm{r}}$ & $\mathrm{Q}_{7}$ \\
\hline
\end{tabular}

Fig. 2. DSM (6) $1-K$ and the fragments $Q$ for the beam, when $m=7$, $n=7, I=1$, in uniform motion. The submatrices have here dimensions: $K_{r}[7 \times 7], V_{r}[7 \times 7]$

\section{Examples of calculating critical states for a bridge}

A fictitious bridge span [18] with a cross-section from fig. 1 was assumed for testing critical states. It is simply supported and in two opposite directions there are three lanes for cars and a bike and pedestrian lane - $3 \mathrm{~m}$ wide each. The width of the girder is $30 \mathrm{~m}$, and the height $-6 \mathrm{~m}$. For torsion at the ends of the span, zero revolutions and the freedom of deplaning were assumed. The girder in each task had a cross-section of a similar drawing and three closed circuits $[17,18]$. In the middle of the outer traffic belt (on eccentricity $e=7.5 \mathrm{~m}$ ) is moving the weight of $20 \mathrm{t}$ or $100 \mathrm{t}$ (force $P=200 \mathrm{kN}$ or $1000 \mathrm{kN}$ ). So, the girder is torsined with the torque $M_{1}=P_{\mathrm{e}}$. Two lengths of girder $L=$ 50 and $100 \mathrm{~m}$ were assumed. Thickness $\delta$ of its walls was chosen in such a way (with an accuracy of $0.01 \mathrm{~mm}$ ) so that under the above force static deflection of the girder were less than $0.001 \mathrm{~L}$.

The change of sign the $\Delta$ value for MD of DSM in the graphs means the critical value [18] occurred in this range of the parameter under test (here: load speed). The obtained numerical values were so large (e.g. $\Delta=6.2 E+p$ ), that they made it impossible to draw it on diagrams. Therefore, were prepared "approximate" diagrams of the values of the calculated power exponents $p$. The $\Delta$ values for twisting are much greater than for the bending of the girder. The size of the mass moving on the bridge during the calculation of $\Delta$ is included in its stiffness and thus in the weight of the girder [18].

\section{Conclusions from previous calculations}

In several previous publications, cited in [17, 18], the deflection lines for beams were shown, over which the mass is moving with uniform motion and different speeds. Similarly, in work [13], bridge beam deflections with the length $L=100 \mathrm{~m}$ were compared. The drawings presented there show that above $360 \mathrm{~km}$ the diagrams of the deflection line show peculiarities (some chaos), which may indicate that the critical speed is exceeded. So, the full assessment of the task should therefore take place after determination of the deflection lines.

\section{Used commercial programs}

The examples given in [18] were carried out using the MS Excel 2007 program. This applies to the arrangement of DSM and the calculation of the value of $\Delta$ for MD and the drawing of graphs for it. In this respect, it is a very convenient tool. The calculation of the MD value for DSM took place in real time (immediately). However, solutions of systems of linear algebraic equations $(6)_{1}$ - as unavailable - will be carried out with the help of own programs - written by present author.

\section{Conclusions}

The examples made did not take into account many problems occurring in the real bridge. Nevertheless, the obtained tabular results and the graphs [18] prepared on their basis confirm the usefulness of JK GZ+US for the assessment of critical speeds for loads that move (not only) over bridges. The values of such speeds depend on the size of the moving mass and the span and mass of the bridge itself. The barrier in planning the size of the task (the number of nodes in the $\mathrm{CzP}$ ) is the computer's ability to remember large numbers.

\section{REFERENCES}

1. Büttner O. Stenker H. "Metalleichtbauten, Band 1, Ebene Raumstabwerke”. Berlin, VEB Verlag für Bauwesen (1970), + „Lekkie konstrukcje metalowe”. Warszawa, Arkady (1974).

2. Gutkowski W., Obrębski J.B., Bauer J., Gierliński J., Rączka J., Żmijewski K. „Obliczenia statyczne przekryć strukturalnych”, Warszawa, Arkady (1980), \& „Statische Berechnung der Raumstabwerke”. Warsz., Werner Verlag/Arkady, (1985). Translation of the book from 1980.

3. Kaliski S. i in. „Drgania i Fale”. Warszawa, PWN (1966).

4. Kączkowski Z. "The method of finite space-time elements in dynamics of structures". J. Techn. Physics. 16, 1 (1975): pp. 69-84.

5. Kączkowski Z. „Metoda czasoprzestrzennych elementów skończonych". Arch. Inż. Ląd. 22, 3, (1976): pp. 365-378.

6. Kączkowski Z. „Niesprzężone układy równań w metodzie elementów czasoprzestrz.(MECZ)", Arch.Inż. Ląd. 32,1 (1986) pp. 39-50.

7. Nowacki W. „Mechanika Budowli”. Warszawa, PWN (1957).

8. Obrębski J.B. „Analiza $i$ synteza numeryczna wielkich układów konstrukcyjnych". Prace IPPT PAN, Warsz. (rozpr. hab.) (1979).

9. Obrębski J.B. „Cienkościenne sprężyste pręty proste”. Warsaw, WPW. (1991): p. 452. Second Ed. Oficyna Wydawnicza Politechniki. Warsz., Warsaw (1999): p.455.

10. Obrębski J.B. „Wytrzymałość materiałów”. Warszawa, Skrypt PW, Micro-Publisher J.B.Obrębski Wyd. Nauk. Druk AGAT (1997).

11. Obrębski J.B. "Uniform criterion for geometrical unchengeability and for instability of structures". Zakopane, Poland,Proc. of the Intern. Conf. on "Stability of Structures". (1997).

12. Obrębski J.B, Szmit R. "Dynamics and dynamical stability of tall buildings", (Invited lecture 30min). Int. Conf. "ICSSD", Taipei, Taiwan, (2000): pp. 85-94.

13. Obrębski J.B. "Examples of some parameters influence on bridges behaviour under moving loadings". 2-d Int.Conf. on "Struct.Eng., Mechanics and Computat.", Cape Town, South Africa, A.A.BALKEMA PUBLISH. Leiden/ London/New York/ Philadelphia/ Singapore. Abstracts vol. p.171, CD, (2004): pp. 859864.

14. J.B. Obrębski: "Multi parametrical instability of straight bars", Ithaca, USA, Cornell University, IASS-IACM 6th Int. Conf. on "Computat. of shell and spatial structures" (2008).

15. Obrębski J.B. "Przykłady wieloparametrowej utraty stateczności prętów prostych”, WAT/Szczyrk, (2014), „XVIII Międz. Szkoła Komput. Wspomaga. Projekt., Wytwarzania i Eksploatacji”, t.2: pp. 125-142 \& Mechanik, 87, 7, (2014) +CD.

16. Obrębski J.B. „Stateczność prętów prostych w świetle obliczonych przykładów”, WAT/Jurata, (2015), „XIX Między. Szkoła Komput. Wspomaga. Projekt., Wytwarzania i Eksploatacji”, t.2: pp.105-122 \& Mechanik, 88, 7, (2015) +CD.

17. Obrębski J.B. „Czasoprzestrzeń w analizie dynamicznej mostów”, WAT/Jurata, (2017), „XXI Międzynar. Szkoła Komput. Wspomagania Projekt., Wytwarzania i Eksploat.", t.2: pp. 91102 oraz „Problems of Mechatronics, Armament, Aviation, Safetyengineering”. Quarterly, VII-IX 2017, vol. 8, 3 (29) (2017): pp.109-126.

18. Obrębski J.B. „Analiza stanów krytycznych mostu w czasoprzestrzeni”, Warszawa/Pisz , „XXII Międzynar. Szkoła Komput. Wspomagania Projekt., Wytwarzania i Eksploat.”,(2018): pp. 291-305.

19. Osiński Z. „Tłumienie drgań mechanicznych”, Warsaw, PWN (1979). 
20. Szmit R. Pręt kompozytowy jako model obliczeniowy budynku wysokiego. Rozpr. Dokt. promotor J.B.Obrębski. Warsaw (2001).

Translation of scientific articles, their computer composition and publishing them on the website www.mechanik.media.pl by original articles in Polish is a task financed from the funds of the Ministry of Science and Higher Education designated for dissemination of science.

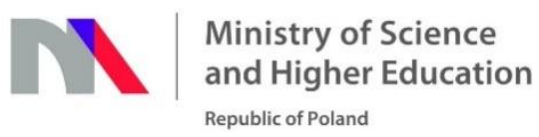

